\title{
Dietary selenium intake by men and women in high and low selenium areas of Punjab
}

\author{
Charanjeet K Hira $^{1, *}$, Kulprakash Partal ${ }^{1}$ and KS Dhillon ${ }^{2}$ \\ ${ }^{1}$ Department of Food and Nutrition, Punjab Agricultural University, Ludhiana- 141 004, Punjab, India: ${ }^{2}$ Department \\ of Soils, Punjab Agricultural University, Ludhiana, India
}

Submitted 6 January 2003: Accepted 25 June 2003

\begin{abstract}
Objective: To determine the selenium intake of adults residing in high and low selenium areas of rural Punjab.

Design: All food samples consumed by the subjects were collected and analysed for selenium content. Based on food intake data and selenium content of foods, the selenium intake of the subjects was calculated. Hair, fingernails and urine samples from a sub-sample of subjects were collected and analysed for selenium.

Setting: Three villages from the selenium-endemic area of Nawan Shahr District and two villages from the non-endemic area of Ludhiana District, Punjab, India, were covered.

Subjects: Forty families from each of the two areas, with one adult male and one adult female in the age range of $20-40$ years, were surveyed. Thus a total of 80 men and 80 women constituted the study sample.

Results: In the selenium-endemic area, the average selenium intake of both men and women was more than nine times that in the non-endemic area and exceeded the maximum tolerable limit in more than $60 \%$ of men. Mean selenium content of the hair, nails and urine of both men and women was tens of times higher than in the nonendemic area.

Conclusions: High selenium intake in the endemic area resulted in high selenium content in the hair, nails and urine of men and women. In addition, clinical symptoms of selenium toxicity were also observed in some of the subjects. Selenium intake in the non-endemic area was marginally below the suggested value. Based on the study results, steps need to be taken to educate the public in the endemic area to avoid selenium toxicity.
\end{abstract}

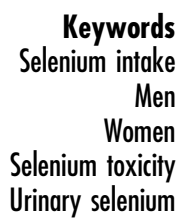

Selenium has been widely known as a toxic element since its discovery by Berzelius in 1817; however, during the recent past, research advances have shown selenium to be an essential nutrient required to combat a number of serious deficiency disorders. Biochemically, selenium is a component of the enzyme glutathione peroxidase, which, along with super dismutase, catalase and vitamin $\mathrm{E}$, protects against damage to cellular components by preventing the accumulation of peroxides in the tissue. Selenium also helps in the prevention of cancer and ageing, and in the treatment of atopic dermatitis and asthma. Selenium is essential for growth and reproduction in rats and is associated with growth in $\operatorname{man}^{1}$.

Selenium is efficiently transferred through the soilplant-animal-human system. Geographic differences in the soil availability of selenium for uptake by plants account for most variations in the selenium content of plants ${ }^{2}$. The amount of selenium in food varies largely with its protein content and the area in which it is grown ${ }^{3}$. Among plant foods, wheat and pulses are rich sources of selenium.
Selenium in food may vary from $<10 \mu \mathrm{g} \mathrm{day}^{-1}$ in seleniumdeficient areas $^{4}$ to about $5000 \mu \mathrm{g}$ day $^{-1}$ in areas where selenosis is endemic ${ }^{5}$. In general, selenium as selenomethionine is more easily absorbed when ingested than is selenite, selenate or selenocystine. Therefore, the selenium in wheat, dairy products and eggs is more easily available ${ }^{6}$.

Severe deficiency of selenium is associated with cardiomyopathy, especially in children and women of childbearing age, which could be prevented by supplementation with sodium selenate ${ }^{7}$. Fatigue followed by sudden death, along with pulmonary oedema and tissue haemorrhage/oedema, are symptoms of acute selenium toxicosis. Chronic selenosis includes effects on keratinised tissue such as loss of hair and lesions on the nails, claws, horn and skin ${ }^{8}$. The role of selenium as an essential element for humans and the identification of pockets of selenium toxicity in the state of Punjab, India led to the present study to determine selenium intake and excretion by adult men and women residing in high and low selenium areas. 


\section{Materials and methods}

A two-stage sampling design was used for the study. The first stage was a purposive selection of the area: i.e. the villages of Bharwa, Jainpur and Simbli in Nawan Shahar District, identified as a high selenium area, and the villages of Gaunsgarh and Meharban in Ludhiana District, selected as a low selenium (non-endemic) area. The second stage involved random selection, from each area, of 40 families with at least one adult man and one adult woman in the age group 20-40 years.

The dietary intake of respondents was recorded for 1 day by interview, with some additional weighing of items, during November 1997 to January 1998. In addition to all the food items consumed, the amount of water consumed by the individuals was also noted. Amounts of raw foods consumed by an individual were calculated from the cooked quantity using the standardised cup method, where cups previously standardised in the laboratory for weight and volume of different cooked foods were used. Various raw food items consumed by the subjects from both areas, including milk, were collected. Drinking water samples were also collected from both areas, as were samples of urine, hair and nails from those subjects who agreed. All samples were collected and stored in decontaminated plastic ware. Food samples except milk were dried in a dehydrator at a temperature of $50 \pm 2^{\circ} \mathrm{C}$. Dried food samples, hair and nail samples were digested using a mixture of three acids $\left(\mathrm{HNO}_{3} / \mathrm{HClO} / \mathrm{H}_{2} \mathrm{SO}_{4}, 9: 3: 1\right)$. For water samples, $500 \mathrm{ml}$ of water sample was evaporated on a hot plate after the addition of $4 \mathrm{ml}$ of $\mathrm{HCl}$ to $15-20 \mathrm{ml}$ and the volume made to $25 \mathrm{ml}$ with de-ionised water. Milk and urine samples $(25 \mathrm{ml})$ were oven-dried, digested with the triple acid mixture and diluted with de-ionised water to known volume. Acid-digested samples were analysed for selenium by atomic absorption spectrometry (AA Varian spectrometer) using the hydride generation method? From the amount of food consumed and the selenium contents of food and water, selenium intake by the subjects was calculated. Urine samples were analysed for creatinine using the method of Karamkar et al. ${ }^{10}$ to express the selenium excretion per unit of creatinine.
In addition to food samples, the height and weight of the subjects were also measured to the nearest $0.1 \mathrm{~cm}$ and $0.5 \mathrm{~kg}$, respectively. Body mass index (BMI) of the subjects was calculated as weight in $\mathrm{kg}$ divided by the square of height in $\mathrm{m}$. Various clinical symptoms of selenium toxicity/deficiency were also recorded in all subjects.

The data were analysed statistically using analysis of variance and $F$-ratios were calculated using standard equations.

\section{Results and discussion}

The study was carried out purposively in a rural area where $70-80 \%$ of the selected subjects belonged to farming families and the remainder were involved in other occupations like labour, small business and service. All the families selected consumed underground water as the sole source of drinking water, which was taken out either through hand-pumps or through tube-wells in both areas. Nearly $45 \%$ of the families used milk from their own animals in both areas and between 40 and $47 \%$ of the families procured milk from milk vendors of the same area. The staple cereal (wheat) consumed was homegrown by nearly $45 \%$ of families in both areas. Consumption of farm-grown legumes and vegetables in the high selenium area (40 and $37.5 \%$, respectively) was greater than in the low selenium area (15 and 25\%, respectively).

Data on anthropometric measurements (Table 1) indicated that the height of men and women in both areas was comparable, while the weight of men and women in the low selenium area (non-endemic) was significantly higher $(P<0.01)$ than that of their counterparts in the high selenium area (endemic). In a study conducted in eight states of India, the National Nutrition Monitoring Bureau ${ }^{11}$ reported that the average height of Indian men and women was 163.4 and $150.6 \mathrm{~cm}$, respectively, and the corresponding values for weight were 56.0 and $43.3 \mathrm{~kg}$. A recent survey carried out by the Government of India ${ }^{12}$ found that the average height of men and women in Punjab was 167.5 and $155.5 \mathrm{~cm}$, respectively, with the corresponding values for weight

Table 1 Height, weight and body mass index (BMI) of men and women from endemic and non-endemic areas. Values are expressed as mean \pm standard error (range)

\begin{tabular}{lccc}
\hline Subjects/area & Height $(\mathrm{m})$ & Weight $(\mathrm{kg})$ & BMI $\left(\mathrm{kg} \mathrm{m}^{-2}\right)$ \\
\hline Males $(n=40)$ & & & \\
Endemic area & $1.74 \pm 0.01(1.60-1.88)$ & $67.70 \pm 2.7(62.0-73.2)$ & $22.30 \pm 0.7(20.2-24.0)$ \\
Non-endemic area & $1.75 \pm 0.01(1.70-1.80)$ & $77.65 \pm 1.3(70.0-85.5)$ & $25.04 \pm 0.9(22.0-28.1)$ \\
$F$-ratio & NS & $10.66^{*}$ & $7.12^{*}$ \\
Females $(n=40)$ & & & \\
Endemic area & $1.61 \pm 0.01(1.60-1.64)$ & $54.50 \pm 2.2(45.0-64.0)$ & $21.05 \pm 0.7(18.5-23.6)$ \\
Non-endemic area & $1.62 \pm 0.01(1.60-1.65)$ & $63.14 \pm 2.0(55.0-72.0)$ & $24.23 \pm 0.7(19.0-30.0)$ \\
F-ratio & NS & $9.5^{\star}$ & $10.1^{*}$ \\
\hline
\end{tabular}

NS-not significant.

* Significant at the $1 \%$ level. 
being 60 and $52.8 \mathrm{~kg}$. Thus both the height and weight of men and women in our sample are higher than the average values for Indian men and women reported previously $^{11,12}$. BMI calculated as weight $/(\text { height })^{2}$ indicated that more than $90 \%$ of subjects had a BMI between 20 and $30 \mathrm{~kg} \mathrm{~m}^{-2}$ and could therefore be classified as normal or obese Grade 1 as per the classification of the World Health Organization (WHO) ${ }^{13}$.

The analysis of samples showed that the selenium content of water and milk in the endemic area was $9.4 \pm 1.0$ and $5.92 \pm 1.0 \mu \mathrm{g} / 100 \mathrm{ml}$, compared with $0.6 \pm 1.0$ and $1.6 \pm 0.5 \mu \mathrm{g} / 100 \mathrm{ml}$, respectively, in the non-endemic area. Selenium content of wheat chapati was $74.2 \pm 19.0 \mu \mathrm{g} / 100 \mathrm{~g}$ in the endemic area while it was less than $0.01 \pm 1.0 \mu \mathrm{g} / 100 \mathrm{~g}$ in non-endemic area. Similarly, the selenium content of most legumes and vegetables in the endemic area was also high compared with the non-endemic area.

Perusal of the dietary survey data indicated that wheat and milk were the major contributors of energy and protein in the diets of the subjects. Wheat was the staple cereal and was consumed as chapati with pulses and/or seasonal vegetables. Wheat intake by men was 346 and $450 \mathrm{~g} \mathrm{day}^{-1}$ in the endemic and non-endemic area, respectively, and contributed $66.5-69.8 \%$ of total protein and $53.3-57.9 \%$ of energy in the daily diet. Similarly, in the diets of women in both areas, wheat contributed $57.5-60.7 \%$ of protein and $46.1-49.5 \%$ of energy. Intake of milk was 315 and $504 \mathrm{ml}$ day $^{-1}$ in men and 268 and $394 \mathrm{ml} \mathrm{day}^{-1}$ in women in the endemic and non-endemic area, respectively. Milk contributed $16.6-22.9 \%$ of energy and $21.5-29.7 \%$ of protein in the diets of men, and 18.6-22.6\% of energy and $24.0-28.7 \%$ of protein in the diets of women.

Data on the selenium intake of the subjects (Table 2) revealed that selenium intake in the endemic area was

Table 2 Selenium intake and selenium content of hair, nails and urine of subjects from endemic and non-endemic areas

\begin{tabular}{|c|c|c|c|c|c|}
\hline \multirow[b]{2}{*}{ Sample/subjects } & \multicolumn{2}{|r|}{$\begin{array}{l}\text { Endemic } \\
\text { area }\end{array}$} & \multicolumn{2}{|c|}{$\begin{array}{l}\text { Non-endemic } \\
\text { area }\end{array}$} & \multirow[b]{2}{*}{ F-ratio } \\
\hline & $n$ & Mean \pm SE & $n$ & Mean \pm SE & \\
\hline \multicolumn{6}{|c|}{ Se intake $\left(\mu \mathrm{g} \mathrm{day}^{-1}\right)$} \\
\hline Men & 40 & $632 \pm 31.2$ & 40 & $65 \pm 2.2$ & $328.5^{\star}$ \\
\hline Women & 40 & $475 \pm 52.8$ & 40 & $52 \pm 1.0$ & $64.5^{\star}$ \\
\hline \multicolumn{6}{|l|}{ Hair ( $\mu \mathrm{g} \mathrm{Se/100} \mathrm{g)}$} \\
\hline Men & 10 & $255 \pm 25$ & 18 & $4.97 \pm 1.4$ & $30.2^{*}$ \\
\hline Women & 11 & $231 \pm 20$ & 14 & $4.77 \pm 1.6$ & $26.9^{*}$ \\
\hline \multicolumn{6}{|c|}{ Nails ( $\mu \mathrm{g} \mathrm{Se} / 100 \mathrm{~g}$ ) } \\
\hline Men & 12 & $440 \pm 193$ & 13 & $10.21 \pm 1.80$ & $28.4^{*}$ \\
\hline Women & 4 & $390 \pm 94$ & 17 & $8.52 \pm 1.75$ & $29.8^{*}$ \\
\hline \multicolumn{6}{|c|}{ Urine ( $\mu \mathrm{g} \mathrm{Se} / 100 \mathrm{ml})$} \\
\hline Men & 25 & $26.7 \pm 6.3$ & 37 & $1.20 \pm 0.3$ & $21.8^{*}$ \\
\hline Women & 29 & $17.0 \pm 3.9$ & 36 & $0.96 \pm 0.1$ & $7.9^{\star}$ \\
\hline \multicolumn{6}{|c|}{ Urine ( $\mu \mathrm{g}$ Se/g creatinine) } \\
\hline Men & 25 & $292 \pm 4.3$ & 37 & $9.15 \pm 0.02$ & $12.28^{*}$ \\
\hline Women & 29 & $225 \pm 4.6$ & 36 & $9.05 \pm 0.3$ & $30.4^{\star}$ \\
\hline
\end{tabular}

SE-standard error.

* Significant at the $1 \%$ level. more than nine times that in the non-endemic area. Cereals contributed 91 and $80 \%$ of selenium for men and women, respectively, of the endemic area, with corresponding values being 31 and $25 \%$ in the non-endemic area. Selenium contribution from milk was 3 and $3.3 \%$ for men and women in the endemic area, compared with 12.4 and $12.0 \%$, respectively, in the non-endemic area. For adults, selenium intakes were $60-125 \mu \mathrm{g}_{\text {day }}{ }^{-1}$ in Japan,

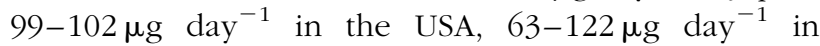
Bangladesh and $234 \mu \mathrm{g}$ day $^{-1}$ in Scotland ${ }^{14}$. However, Yang et al..$^{15}$ reported daily selenium intakes ranging from $7-11 \mu \mathrm{g}$ in an area affected by Keshan's disease to $4990 \mu \mathrm{g}$ in an area affected by chronic selenosis in China. A daily intake of $50-400 \mu \mathrm{g}$ has been suggested as optimum ${ }^{16}$. The US Food and Nutrition Board ${ }^{17}$ has suggested 70 and $50 \mu \mathrm{g}$ as the daily requirement for men and women, respectively. Yang et al. ${ }^{18}$ suggested $17 \mu \mathrm{g} \mathrm{day}^{-1}$ as the minimum dietary selenium requirement for the prevention of Keshan's disease, while $40 \mu \mathrm{g}$ day $^{-1}$ was considered as an adequate dietary requirement. They further suggested 600 and $400 \mu \mathrm{g}$ as the daily maximum and safe intake of dietary selenium, respectively. Daily selenium intake required to maintain characteristic fingernail changes resulting from toxicity was reported to be $1600 \mu \mathrm{g}$, while the intake needed to recover from fingernail lesions resulting from deficiency was $819 \mu \mathrm{g}$ day $^{-1}$. Based on studies carried out in China, $\mathrm{WHO}^{19}$ has suggested 0.39 and $0.42 \mu \mathrm{g} \mathrm{Se} \mathrm{kg}^{-1}$ body weight as the lower safe limit for adult women and men, respectively, which translates into 19.5 and $25.2 \mu \mathrm{g}$ for reference Indian women and men. It has further been reported that a dietary selenium intake of $41 \mu \mathrm{g} \mathrm{day}{ }^{-1}$ was sufficient to saturate the plasma glutathione level of a $60-\mathrm{kg}$ man. Thus, considering $40 \mu \mathrm{g} \mathrm{day}^{-1}$ of selenium as the desired intake, subjects in the non-endemic area of the present study were consuming adequate selenium but their intake ranged from the sub-maintenance to maintenance allowance considering the 70 and $50 \mu \mathrm{g}$ daily selenium requirement for men and women, respectively. However, their intake was far lower than the safe level of $400 \mu \mathrm{g} \mathrm{day}^{-1}$. In the endemic area, $15 \%$ of men and one woman consumed more than the $819 \mu \mathrm{g}$ day $^{-1}$ that results in metabolic changes. Furthermore, $60 \%$ of men and $7.5 \%$ of women consumed more than $600 \mu \mathrm{g}_{\text {day }^{-1}}{ }^{-1}$ which is considered to be the maximum limit of selenium intake (Table 3).

Mean selenium content of hair from men and women from the high selenium area was 40-50 times that for subjects in the low selenium area (Table 2). Yang et al. ${ }^{5}$ reported that selenium content of hair in men from a high selenium area with chronic selenosis was $3220 \mu \mathrm{g} / 100 \mathrm{~g}$, which decreased to $370 \mu \mathrm{g} / 100 \mathrm{~g}$ among men in an area with high selenium without selenosis and $36 \mu \mathrm{g} / 100 \mathrm{~g}$ for men residing in an adequate selenium area. Dhillon and Dhillon ${ }^{20}$ have reported values of 1311 and $188 \mu \mathrm{g} \mathrm{Se} / 100 \mathrm{~g}$ of fingernails and hair, respectively. The selenium content of the hair of subjects in the 
Table 3 Classification of subjects based on selenium intake. Values are expressed as number of subjects (\%)

\begin{tabular}{lcc}
\hline $\begin{array}{l}\text { Selenium intake } \\
\left(\mu \text { day }^{-1}\right)\end{array}$ & Men $(n=40)$ & Women $(n=40)$ \\
\hline $\begin{array}{l}\text { Endemic area } \\
<300\end{array}$ & $1(2.5)$ & \\
$300-600$ & $15(37.5)$ & $1(2.5)$ \\
$600-900$ & $21(52.5)$ & $36(90.0)$ \\
$900-1200$ & $3(7.5)$ & $2(5.0)$ \\
$>1200$ & 0 & 0 \\
Non-endemic area & & $1(2.5)$ \\
$<40$ & 0 & 0 \\
$40-50$ & $9(22.5)$ & $15(37.5)$ \\
$50-70$ & $8(20.0)$ & $25(62.5)$ \\
$>70$ & $23(57.5)$ & 0 \\
\hline
\end{tabular}

present study was less than in subjects showing clinical symptoms of selenosis but higher than in healthy subjects. Similarly, the mean selenium content of fingernails among men and women from the endemic area (440 and $390 \mu \mathrm{g} / 100 \mathrm{~g}$, respectively) was much higher than in those from the non-endemic area (10.21 and $8.52 \mu \mathrm{g} / 100 \mathrm{~g}$, respectively). Bratakos et al. ${ }^{21}$ reported that mean selenium content of the fingernails of healthy Greeks was $53.6 \mu \mathrm{g} / 100 \mathrm{~g}$ and that the differences between males and females were significant. Dhillon and Dhillon ${ }^{20}$ reported that the fingernail selenium content of individuals with selenosis and healthy subjects from a high selenium area was 1582 and $228 \mu \mathrm{g} / 100 \mathrm{~g}$, respectively. The results indicate that, since the study by Dhillon and Dhillon in $1997^{20}$, awareness campaigns in the high selenium area have resulted in significant decreases in hair and nail selenium contents of subjects residing in that area. Although the fingernail selenium content of subjects in the endemic area was much higher than that reported for healthy subjects, the values in the non-endemic area were lower and may indicate selenium deficiency among those subjects. In the endemic area, selenium concentrations in hair and nails were found to be significantly and positively associated $(r=0.826, P<0.01)$. Furthermore, urinary selenium excretion in the endemic area was much higher in both men and women (26.7 and $17.01 \mu \mathrm{g} / 100 \mathrm{ml})$, compared with their counterparts in the non-endemic area $(1.2$ and $0.96 \mu \mathrm{g} / 100 \mathrm{ml})$. Novarro et $a{ }^{9}{ }^{9}$ reported that persons consuming $54.9 \mu \mathrm{g}$ of dietary selenium in daily diets excreted 0.46 to $5.03 \mu \mathrm{g} \mathrm{Se} / 100 \mathrm{ml}$ of urine. Urinary selenium excretion of subjects from the non-endemic area was towards the lower side of this range, while in the endemic area it was three to five times higher than the upper range. The data on clinical symptoms of toxicity (Table 4) revealed that $17.5 \%$ of men and $15 \%$ of women showed loss of hair. However, more women showed blackening and loss of nails than did men.

Thus it may be concluded that the mean selenium intake by men and women in the endemic area was more than
Table 4 Clinical symptoms of selenosis in subjects from the endemic area. Values are expressed as number of subjects experiencing the symptom

\begin{tabular}{lcc}
\hline Symptom & Men $(n=40)$ & Women $(n=40)$ \\
\hline Loss of hair & 7 & 6 \\
Tooth decay & 0 & 2 \\
Black teeth & 0 & 3 \\
Brown stains on teeth & 0 & 1 \\
Longitudinal streaks on nails & 1 & 1 \\
Blackening of nails & 2 & 6 \\
Breaking of nails & 1 & 2 \\
Brittle nails & 0 & 1 \\
Loss of nails & 1 & 5 \\
Headache & 2 & 1
\end{tabular}

More than one symptom was allowed per subject.

$600 \mu \mathrm{g} \mathrm{day}^{-1}$, which is the upper safe limit, and the mean selenium content in their hair, nails and urine content was also high. Therefore, education of the people in this area is recommended.

\section{References}

1 Casey CE, Hambidge KM. Trace element deficiencies in man. Advances in Nutritional Research 1980; 3: 46-8.

2 Levander OA. A global view of human selenium nutrition. Annual Review of Nutrition 1987; 7: 227-50.

3 Burk RF. Selenium in nutrition. World Review of Nutrition and Dietetics 1978; 30: 88-108.

4 Luo X, Wei H, Yang C, Xing J, Qiao C, Feng Y, et al. Selenium intake and metabolic balance of ten men from a low selenium area of China. American Journal of Clinical Nutrition 1985; 43: 31-7.

5 Yang G, Wang S, Zhou R, Sun S. Endemic selenium intoxication of humans in China. American Journal of Clinical Nutrition 1983; 37: 872-81.

6 National Academy of Science (NAS)/National Research Council (NRC). Selenium in Nutrition. Washington, DC: NAS/NRC Board on Agriculture, 1983.

7 Virtamo J, Huttunen JK. Selenium. In: Aitio A, Aro A, Jaivisalo $\mathrm{J}$, eds. Trace Elements in Health and Disease. Cambridge: The Royal Society of Chemistry, 1993; 127-40.

8 Kumar A. Selenium Nutrition. Hyderabad: Indian Council of Medical Research, 1995; 29: 13-21.

9 Novarro M, Lopez H, Lopez MC, Perez V. Determination of $\mathrm{Se}$ in urine by hydride generation atomic absorption spectrometry. Journal of AOAC International 1996; 79: 773-6.

10 Karamkar MG, Pandav CS, Krishnamachari K. Principles and Procedures for Iodine Estimation. New Delhi: Indian Council of Medical Research, 1986.

11 National Nutrition Monitoring Bureau. National Nutrition Monitoring Bureau Report Surveys. Hyderabad: National Institute of Nutrition, Indian Council of Medical Research, 1991.

12 Government of India. India Nutrition Profile. New Delhi: Department of Women and Child Development, Ministry of Human Resource Development, Government of India, 1998.

13 World Health Organization (WHO). Physical Status: The Use and Interpretation of Anthropometry. Report of WHO Expert Committee. WHO Technical Report Series No. 854E. Geneva: WHO, 1995.

14 Thompson CD, Robinson MF. Selenium in human health and disease with emphasis on those aspects peculiar to 
New Zealand. American Journal of Clinical Nutrition 1980; 33: 303-23.

15 Yang G, Ge K, Chen J, Chen X. Selenium related endemic diseases and daily selenium requirement of humans. World Review of Nutrition and Dietetics 1988; 55: 98-152.

16 Aaseth J. Optimum selenium levels in animal products for human consumption. Norwegian Journal of Agricultural Science 1993; 11: 121-6.

17 US Food and Nutrition Board. Recommended Dietary Allowances, 9th revised ed. Washington, DC: National Academy of Sciences, 1980.

18 Yang G, Xia Y, Yang GQ, Xia YM. Studies on human dietary requirement and safe range of dietary intake of selenium in
China and their application in the prevention of related endemic diseases. Biomedical and Environmental Sciences 1995; 8: 187-201.

19 World Health Organization (WHO). Trace Elements in Human Nutrition and Health. Geneva: WHO, 1996.

20 Dhillon KS, Dhillon SK. Distribution of seleniferous soil in north west India and associated toxicity problems in the soilplant-animal-human continuum. Land Contamination and Reclamation 1997; 5: 313-22.

21 Bratakos MS, Kanaki HC, Vasiliov Waite A, Ioannaou PV. The nutritional selenium status of healthy Greeks. Science of the Total Environment 1990; 91: 161-76. 